Original Article

\title{
The inhibitory effect of Cannabis Sativa L. and Morus nigra L. against lipid peroxidation in goat liver and brain homogenates
}

\author{
O efeito inibitório de Cannabis Sativa L. e Morus nigra L. contra a peroxidação lipídica \\ em homogenatos de fígado e cérebro de cabra
} \author{
A. Hussaine, Q. Abbas ${ }^{\mathrm{a}}$ (D) , M. Ali ${ }^{\mathrm{d}}$ (D) and S. A. E. Bukhari ${ }^{\mathrm{b}}$ (D) \\ aKarakoram International University, Department of Biological Sciences, Gilgit, Pakistan \\ bUniversity of Poonch, Department of Chemistry, Rawalakot, Pakistan \\ 'University of Azad Jammu and Kashmir, Department of Botany, AJK, Pakistan \\ dKarakorum International University, Department of Chemistry, Gilgit, Pakistan \\ eKarakoram International University, Department of Food and Agriculture, Gilgit, Pakistan
}

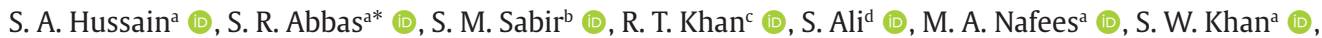

\begin{abstract}
The present study was aimed to evaluate the antioxidant potential and inhibitory effect of Cannabis sativa and Morus nigra against lipid peroxidation in goat brain and liver homogenates. The formation of free radicals, highly reactive oxygen species (ROS) and reactive nitrogen species (RNS) is a normal metabolic process for cellular signaling and countering the antigens. However, they may cause serious damage if they produced at amplified tolls. In addition, metabolic disorders also serve as sources of these reactive species. Although the issue can be addressed through supplements and other phytochemicals. In this study, two plant species were evaluated for their biological potential by employing a spectrum of antioxidant assays. The antioxidant activity was performed by lipid peroxidation assay. The water extract prepared from leaves of Cannabis sativa and Morus nigra showed significant $(\mathrm{P}<0.05)$ inhibition as compared to control i.e., $522.6 \pm 0.06$ and $659.97 \pm 0.03$ $\mu \mathrm{g} / \mathrm{mL}$ against iron-induced lipid peroxidation in goat brain homogenate while the inhibitions were $273.54 \pm 0.04$ and $309.18 \pm 0.05 \mu \mathrm{g} / \mathrm{mL}$ against nitroprusside induced lipid peroxidation of the brain. The iron and nitroprusside induced lipid peroxidation was also significantly inhibited by leaf extracts of Cannabis sativa and Morus nigra in liver homogenates such as $230.63 \pm 0.52$ and $326.91 \pm 0.01 \mu \mathrm{g} / \mathrm{mL}$ (iron-induced) while $300.47 \pm 0.07$ and $300.47 \pm 0.07 \mu \mathrm{g} / \mathrm{mL}$ (nitroprusside induced), respectively. The extracts of Cannabis sativa extract showed promising activity $(96.04 \pm 0.060 \%)$ against DPPH radicals while Morus nigra showed a moderate activity $(34.11 \pm 0.120 \%)$. The results suggest that different accessions of Cannabis sativa and Morus nigra are a potential source of antioxidants and have a therapeutic effect against disease induced by oxidative stress and hence can be used for novel drug discovery and development.
\end{abstract}

Keywords: Cannabis sativa, Morus nigra, antioxidant activity, lipid peroxidation, ABTS assay, liver and brain homogenates.

\begin{abstract}
Resumo
O presente estudo teve como objetivo avaliar o potencial antioxidante e o efeito inibitório de Cannabis sativa e Morus nigra contra a peroxidação lipídica em homogenatos de cérebro e fígado de cabras. A formação de radicais livres, espécies altamente reativas de oxigênio (ROS) e espécies reativas de nitrogênio (RNS), é um processo metabólico normal para sinalização celular e combate aos antígenos. No entanto, eles podem causar sérios danos se forem produzidos em portagens ampliadas. Além disso, distúrbios metabólicos também servem como fontes dessas espécies reativas, embora o problema possa ser resolvido por meio de suplementos e outros fitoquímicos. Neste estudo, duas espécies de plantas foram avaliadas quanto ao seu potencial biológico, empregando um espectro de ensaios antioxidantes. A atividade antioxidante foi realizada por ensaio de peroxidação lipídica. O extrato de água preparado a partir de folhas de Cannabis sativa e Morus nigra mostrou inibição significativa $(P<0,05)$ em comparação com o controle, ou seja, 522,6 $\pm 0,06$ e 659,97 $\pm 0,03 \mu \mathrm{g} / \mathrm{mL}$ contra peroxidação lipídica induzida por ferro em homogenato de cérebro de cabra, enquanto as inibições foram 273,54 $\pm 0,04$ e 309,18 $\pm 0,05 \mu \mathrm{g} / \mathrm{mL}$ contra a peroxidação lipídica do cérebro induzida por nitroprussiato. A peroxidação lipídica induzida por ferro e nitroprussiato também foi significativamente inibida por extratos de folhas de Cannabis sativa e Morus nigra em homogenatos de fígado, como 230,63 $\pm 0,52$ e 326,91 $\pm 0,01 \mu \mathrm{g} / \mathrm{mL}$ (induzida por ferro), enquanto 300,47 $\pm 0,07$ e $300,47 \pm 0,07 \mu \mathrm{g} / \mathrm{mL}$ (induzida por nitroprussiato), respectivamente. Os extratos do extrato de Cannabis sativa apresentaram atividade promissora (96,04 $\pm 0,060 \%$ ) contra os radicais DPPH enquanto Morus nigra apresentou atividade moderada (34,11 $\pm 0,120 \%$ ). Os resultados sugerem que diferentes acessos de Cannabis sativa e Morus nigra são uma fonte potencial de antioxidantes e têm efeito terapêutico contra doenças induzidas por estresse oxidativo e, portanto, podem ser usados para a descoberta e desenvolvimento de novos medicamentos.
\end{abstract}

Palavras-chave: Cannabis sativa, Morus nigra, atividade antioxidante, peroxidação lipídica, ensaio ABTS, homogenatos de fígado e cérebro.

*e-mail: dr.syedrizwan@kiu.edu.pk

Received: January 3, 2021 - Accepted: June 30, 2021

This is an Open Access article distributed under the terms of the Creative Commons Attribution License, which permits unrestricted use, distribution, and reproduction in any medium, provided the original work is properly cited. 


\section{Introduction}

The medicinal plants are of the main interest for medicines and scientific research and many important agents having medicinal importance were being isolated from these plants (Rana et al., 2021). The research teams have isolated many important substances from these plants for the formulation of new medicines. Many important bioactive compounds like flavonoids, tannins, phenols and alkaloids have a vital role in drug development (Khalil et al., 2021). Phytochemicals originated from plants that are mostly non-nutritional but control many important functions in human beings. The estimated number of superior plants which includes angiosperms and gymnosperms are 250000 and this potential source of the plants is largely unexploited and only $6 \%$ were evaluated for their biological activities and out of these only $15 \%$ were estimated on the phytochemical plant (Faria et al., 2021). Moreover, we are being challenged by the revival of new diseases mainly those which are caused by oxidative stress. However synthetic antioxidants can cause toxicological problems so the research was progressed to isolate the plant's based natural antioxidants (Sabir et al., 2020).

A balance between the body antioxidant system and the production of the reactive oxygen system is important for normal body function. An increase in ROS disturbs the body equilibrium and causes body stress. Several of these active ingredients have therapeutic importance for that reason medicinal plants normally recommended for the prevention and treatment of many diseases and still considered the fundamental cause of medicine in pharmaceutical industries (Abbas et al., 2014; Panossian et al., 2021). Diabetes mellitus is being considered a metabolic disease and results from the deficiency of insulin or inactivity of insulin function which ensues in hyperglycemia, alterations in hydrated carbons and critical biological molecules in our body. The cases of diabetes mellitus have always been on the rise and the main reasons for diabetes mellitus have been ageing, mental stress, depression and lack of balanced diet etc. (Patil et al., 2011). The plants possess many antioxidants which can be used to treat the diseases like liver toxicity and arthritis (Lee et al., 2021). Significant reviews have been published on the relationship between oxidative damages and the development of diseases like cancer, liver diseases, ageing, arthritis, diabetes, acquired immune deficiency syndrome (Fatima et al., 2021). The antioxidant prohibits oxidative damage to different macromolecules like proteins, lipids and nucleic acids (Kampa and Castanas, 2008). The reaction of these free radicals with these macromolecules can stimulate the process of apoptosis which can result in cardiovascular and neurobiological disorders (Chen et al., 2021). Antioxidants have an important role in the cure of diseases like diabetes by inhibiting peroxidation chain reaction. The antioxidants like vitamin $\mathrm{E}, \mathrm{C}$, flavonoids and tannins have an important role in the treatment of diabetes (Patil et al., 2011). Many molecules such as miglitol and acarbose are strong competitive stoppers of the $\alpha$-amylases and mitigate postprandial absorption of the many disaccharides and starch. Such types of synthetic medicines mitigate glucose level but on the other hand, becomes the primary reason of many sides effects and becomes unsuccessful to treat diabetes and other related complications (Ortiz-Andrade et al., 2007). The compounds like phenols in medicinal plants proved to possess an insulin-like influence on sugar utilization. These phenolic molecules are seen to prevent important enzymes linked with diabetes mellitus 2 and lipid peroxidation (Anwar et al., 2021). The current work was aimed at the determination of the protective effect of Cannabis sativa and Morus nigra leaf extracts against oxidative stress. Moreover, the antioxidant effect was assessed by employing a spectrum of bioassays. Exciting results were disclosed in this study and summarized in subsequent sections as of its use as alternative and complimentary medicines (CAMs). These findings may be useful for novel drug discovery and development.

\section{Materials and Methods}

This study was carried out in the laboratory of the department of the Biological Sciences Karakoram International University, Gilgit-Baltistan, Pakistan.

\subsection{Plant material}

The plants leaves collected from different parts of Gilgit-Baltistan from March 2018 to August 2018 and were examined by a taxonomist at Karakoram International University Gilgit.

\subsection{Chemical materials}

Malonaldehyde-bis-dimethyl acetal (MDA), gallic acid, Thiobarbituric acid (TBA), 2,2- diphenyl-1-picrylhydrazyl (DPPH), phenanthroline and quercetin were bought from Sigma-Aldrich (St. Louis, MO, USA). Iron (II) sulphate was acquired from Lahore, Pakistan.

\subsection{Plant extract preparation}

The plant extracts were made by using the method of (Sabir et al., 2012). The dry weight of $25 \mathrm{~g}$ of leaves was equally taken and ground into powder separately and mixed with $(100 \mathrm{ml})$ of hot water for 15 minutes and allowed to cool and later filtered by using Whatman paper. The extracts were then mixed with $50 \mathrm{ml}$ of acetone and ethanol add this info in the abstract part and placed for three days at room temperature and then again filtered by using the Whatman paper. The last residue was more segregated two times and finally, the whole extract was collected in a rotational evaporator $\left(50^{\circ} \mathrm{C}\right)$. Serial dilutions were made to identify the effective concentration of plants.

\subsection{DPPH radical scavenging activity}

To check the DPPH (radical scavenging) activity (ethanol, acetone and aqueous solution $0.25 \mathrm{mM}$ ) the method of (Hatano, Kagawa, Yasuhara, \& Okuda, 1988) was used. Then $(0.25 \mathrm{mM})$ of DPPH radical $(0.5 \mathrm{~mL})$ solution was added into ethanol, acetone and aqueous extract solution $(1 \mathrm{~mL})$ in concentration from the $(25-200 \mu \mathrm{g} / \mathrm{mL})$. After shaking, the mixture put for 30 minutes into the shade of dark and then absorbance was checked in a spectrophotometer at 
$517 \mathrm{~nm}$. The ability to scavenge DPPH radical determined as Formula 1:

$$
\text { Scavenging }(\text { percent })=[(\text { Ao-A1)/Ao })] \times 100
$$

Ao indicates the absorbance of the control and A1 describes the absorbance of the sample. The entire results were carried out in triplicate.

\subsection{ABTS radical scavenging assay}

ABTS assay was performed by employing the method earlier reported by Lee and co-workers with certain modifications (Lee et al., 2015).

The reaction set-up contained $5 \mathrm{~mL}$ of $7 \mathrm{mM}$ ABTS radicals in $88 \mu \mathrm{L}$ of $140 \mathrm{mM}$ potassium persulfate. The reaction mixture was allowed to stand for $16 \mathrm{~h}$ in the dark at room temperature for the generation of radicals. The mixture was then diluted with water. For the determination of ABTS radical scavenging activity of leaf extracts of $C$. sativa and M. nigra, $100 \mu \mathrm{L}$ ABTS radical was reacted with $100 \mu \mathrm{L}$ of plant extracts at different concentrations. The assay was performed in a 96-well microplate. The mixture was incubated at room temperature for $10 \mathrm{~min}$. Finally, absorbance was recorded at $734 \mathrm{~nm}$ by using a spectrophotometer (Spectra Max, Molecular Devices USA). A vehicle control was set in parallel for the comparison of results having absolute methanol instead of sample. The radical scavenging activity was calculated by using the following Formula 2

$$
\% R S A=1-(A S / A C) * 100
$$

Where, AS is the absorbance of sample and AC is the absorbance of control.

\subsection{TBARS assay}

TBARS assembly was found out by using an altered procedure (Ohkawa et al., 1979). To anesthetize animals the chemical chloroform was applied. Livers were promptly evacuated and put on ice. In cool 100mM tris buffer with the $\mathrm{pH} 7.4(1: 10 \mathrm{w} / \mathrm{v})$ tissues $(1: 10, \mathrm{w} / \mathrm{v})$ were homogenized and then centrifuged at $(1,000 \mathrm{x}$ g for 10 minute).The final

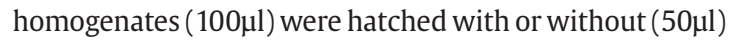
of newly formed oxidant (iron and sod. nitroprusside) and various concentrations of extract together with the best possible volume of deionized water to give the total volume of $\left(300 \mu \mathrm{l}\right.$ at $37{ }^{\circ} \mathrm{C}$ for 60 minutes). The colored

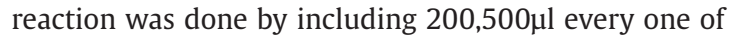
8.1\% (Sodium dodecyl sulfate SDS) acetic acid pH3.4 and $0.6 \% \mathrm{TBA}$, individually. The Reaction mixtures included sequential dilutions of (0.03mM) normal (MDA) (1.5-9nM), was incubated for the 60 minutes at $97^{\circ} \mathrm{C}$. After cooling the absorbance of tubes was checked at a wavelength of $(532 \mathrm{~nm})$ in a spectrophotometer.

\section{Results and Discussion}

\subsection{DPPH radical scavenging activity}

The extracts were obtained by boiling the plant material in hot water subsequently mixed with different organic solvents like ethanol and acetone. The extracts were further tested for antioxidant activity by an array of bioassays. Antioxidants" are chemicals that are famous to neutralize free radicals and their damaging effects. The radical scavenging activities by antioxidants of extracts were determined by the measurement of the scavenging of stable DPPH radicals (Figure 1). The leaf extracts of Cannabis sativa and Morus nigra showed radical scavenging activity however, the leaf extract of Cannabis sativa showed promising activity, though it exhibited a dose-dependent activity it has shown the highest potential $(96.04 \pm 0.060 \%)$ at $400 \mu \mathrm{g} / \mathrm{mL}$ as shown by the $>50 \%$ result to scavenge the DPPH radical (Figure 1). It was observed that there were significant $(p<0.05)$ variations between both plants for the DPPH radical scavenging activity. Based on concentration, the highest antioxidant activity was observed at $96.04 \%$ for C. sativa leaf extract and $34.11 \%$ for $M$. nigra at $400 \mu \mathrm{g} / \mathrm{mL}$ while the least antioxidant activity was for extracts was observed at $25 \mu \mathrm{gg} / \mathrm{mL}$ (24.18 and 19.14\%, respectively).

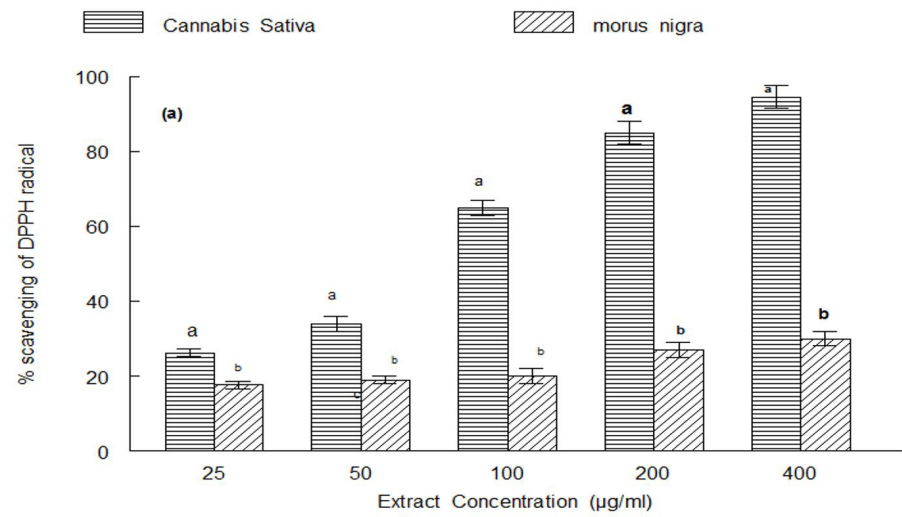

Figure 1. DPPH radical scavenging of the plant extracts of Cannabis sativa and Morus nigra (leaf extracts). Values in the figures which share the different letters are significantly $(p<0.05)$ different from one another by DMRT. 
Furthermore, at 50 (ug/ml) Cannabis sativa showed 37.5\% while Morus nigra showed an $18 \%$ inhibitory effect against Lipid peroxidation in goat liver and brain homogenates. In the same way, at 100 and $200 \mathrm{ug} / \mathrm{ml}$, Cannabis sativa exhibited $66.4 \%$ and $84.5 \%$ while Morus nigra showed $19.5 \%$ and $26.4 \%$ inhibitory effect against DPPH radicals. Antioxidants work at different stages (prevention, interception, and repair) and perform their functions by different methods as reducing agents by donating the hydrogen, by quenching of singlet oxygen, and by acting as the chelators, trapping free radicals (Devasagayam et al., 2004). The high DPPH radical scavenging activities of these extracts of the plant are suggested to use against the diseases arising from the free radical attack like diabetes. Antioxidants like vitamin C, N-acetylcysteine, and $\alpha$-lipoic acid are helpful in the reduction of diabetic complications, representing that, it may be advantageous either by the ingestion of natural antioxidants or by dietary supplementation. Earlier studies conducted by (Zagórska-Dziok et al., 2021) independently in 2021 and 2019 , respectively on the biological potential of $C$. sativa using different methodologies. However, these studies supported the antioxidant potential of the target plant in the current study. Thus this plant would have crucial application in the food and cosmetic industry for having potential antioxidant constituents. Similarly, Morus nigra showed moderate activity, although the activity is quite appropriate for a fruit that is consumed as food non-edible plants must have a high content of antioxidants (Sabir et al., 2020). There antioxidant potential was reported in the perspective of the diseases in which oxidative stress is an allied complication (Silva et al., 2010).

\subsection{Quantification of total antioxidant activity (ABTS assay)}

The values of the total antioxidant activity (TAA) were expected by the Trolox equivalent antioxidant capacity (TEAC) test (Miller and Rice-Evans, 1996). In this test, we calculated the relative capability of the antioxidants to scavenge ABTS_+ radical, compare to the antioxidant potency of Trolox is used as a standard. In Figure 2 shows that by increasing the concentration of plant extract in all extract aqueous solutions the percentage of inhibition increase while in all of these at higher concentration $(250 \mu \mathrm{g} / \mathrm{ml})$ of extract, Cannabis sativa extract has higher inhibition (31\%) as compared to the Morus nigra (22\%) extract inhibition while at (100ug/ml) Cannabis sativa showed 26\% whereas Morus nigra exhibited 10\% inhibition. Similarly, at (50ug/ml) least inhibitory effect was observed in both plants i.e Cannabis sativa $18 \%$ whereas Morus nigra was recorded to show an $8 \%$ inhibitory effect respectively which is shown in Figure 2.

The scavenging method of ABTS work at a specific range of absorbance, i.e $734 \mathrm{~nm}$, from a region of visible range. It required a short time for the reaction, which should be applied as an index, due to antioxidant activity of extract of the plant can be referred (Floegel et al., 2011). ABTS'+ is a stable radical that can dissolve in an aqueous and as well as polar solvent. This method is very easy to be performed, which is why it is mostly reported (Alam et al., 2013).

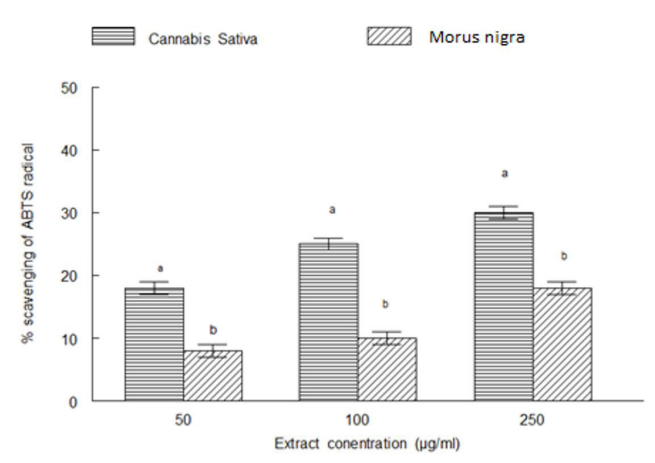

Figure 2. ABTS radical scavenging activity of Cannabis sativa and Morus nigra (leaves extracts). Values in the figure which share the different letters are significantly $(p<0.05)$ different from one another by DMRT.

\subsection{Production of the TBARS in liver and brain tissues}

This study was aimed to find out the importance of Cannabis Sativa and Morus nigra against diabetes by using antioxidant profiling. Lipid peroxidation in the goat liver was induced with iron $(10 \mu \mathrm{M})$ and sodium nitroprusside $(5 \mu \mathrm{M})$ and the antioxidant effect of Cannabis Sativa and Morus nigra extracts was studied. There was a statistically, important rise in the formation of the TBARS in ferrous sulfate and the SN P induced in liver homogenate as compared to the normal or basal as shown in (Figure 3) However, Figure 3 reveals that treatment with Cannabis Sativa and Morus nigra caused the concentration-dependent inhibition of the TBARS production, and bring the values close to basal level. The maximum suppression of TBARS induced with iron in liver homogenate was observed at (400ug/ml) and minimum suppression was recorded at (25ug/ml) as compared to basal and control. Similarly (Figure 4) shows that when TBARS were produced by inducing with sodium nitroprusside (SNP) and tested the efficacy of plant extracts then it was observed that plants had significant on TBARS inhibition. Figure 4 reveals that maximum inhibition was recorded at $400 \mathrm{ug} / \mathrm{ml}$ and minimum suppression was observed at $25 \mathrm{ug} / \mathrm{ml}$ respectively as compared to basal and control groups. One of the objectives of this study was to evaluate the protective effect of $C$. sativa and $M$. nigra against lipid peroxidation which is a malicious metabolic process observed in a variety of diseases, the results are summarized in Figure 3 and 4 . The results show the suppression of TBARS production induced by Fe (II) and SNP in goat's liver homogenate when applied plant extract at different concentrations. A trend in concentration-dependent effect on TBARS production was observed. The incubation of the liver tissues in the presence of $10 \mu \mathrm{M} \mathrm{Fe}$ (II) and $5 \mu \mathrm{M}$ SNP caused an increase in the lipid peroxidation which was considerably decreased both the extracts i.e., C. sativa and $M$. nigra. Here we have used the pro-oxidant agents that induce lipid peroxidation through different mechanisms. Free iron can cause neurotoxicity (Bostanci and Bağirici, 2008) via stimulation of the Fenton reaction (Finkel and Holbrook, 2000). The increased level of lipid peroxidation in presence of the Fe (II) could be accredited to the fact 


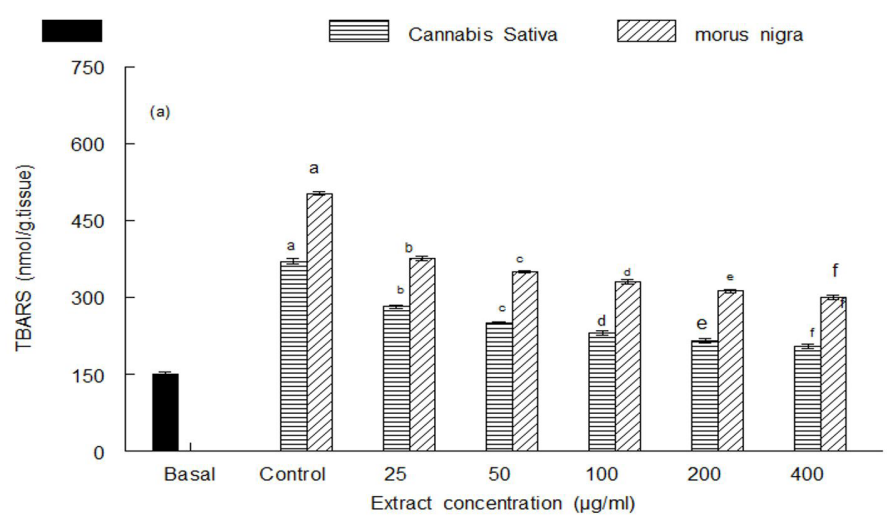

Figure 3. TBARS iron-induced in goat liver homogenate. Values in the figure which share the different letter are significantly ( $\mathrm{p}<0.05)$ which are different from the each other through DMRT.

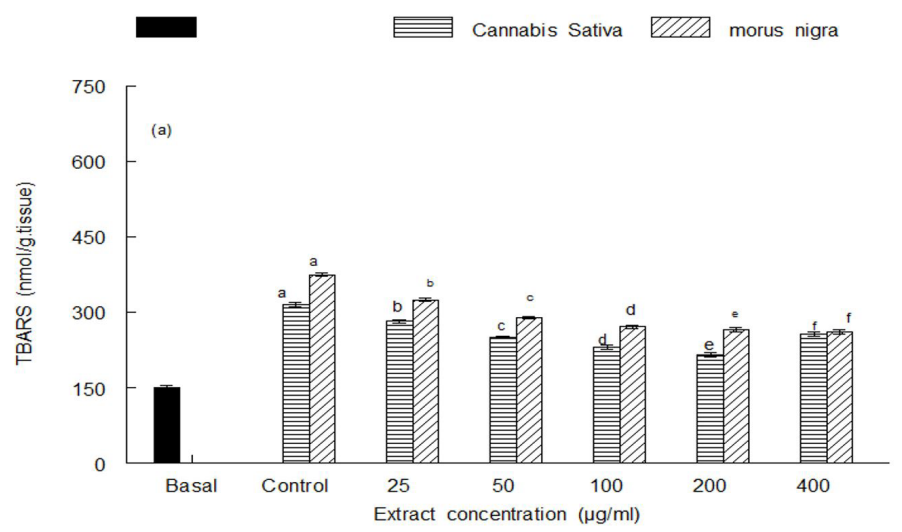

Figure 4. TBARS SNP induced in goat liver. Values in a figure which share the different letter are significantly $(\mathrm{p}<0.05)$ which are different from one another through DMRT.

that the $\mathrm{Fe}$ (II) can catalyze the one-electron transfer reaction that generates the $\mathrm{ROS}$ such as the reactive $\mathrm{OHo}$ which is created from $\mathrm{H} 2 \mathrm{O} 2$ through Fenton reaction. Iron also results in the decomposition of the lipid peroxides, thus generating peroxyl, alkoxyl radicals which favor the propagation of lipid oxidation (Zago et al., 2000). Sodium nitroprusside is an antihypertensive drug that acts through relaxation of the vascular smooth muscle; accordingly, it dilates the veins and peripheral arteries. However, earlier studies have shown that the photodegradation of the SNP eventually produces, $[(\mathrm{CN}) 5-\mathrm{Fe}] 3+$ and $[(\mathrm{CN}) 4-\mathrm{Fe}] 2+$ species (Bates et al., 1991). Nitric oxide is the molecule that is regarded as a universal neuronal messenger in the central nervous system and is also involved in the pathophysiology of disorders like diabetes (Bajaj and Khan, 2012), Alzheimer's and Parkinson's disorders, trauma, and seizures, stroke, etc. (Bolanos and Almeida, 1999). The protection offered through aqueous extract in the goat liver and the brain homogenates confirms that the antioxidant activity of extract indicates its therapeutic uses in accidental toxicities which results from the potential overload of the SNP and iron. Indeed distinct antioxidant activities of the plant extract could indicate that they were acting via the distinct mechanism. Even though this can be the case, plant extract should be inhibiting the common final (or downstream) pathway in the polyunsaturated fatty acids peroxidation. Thus, we cannot exclude that a single mechanism is involved in anti-oxidant of tested extract. Cannabis Sativa and Morus nigra are best antioxidant and having ability to control diabetes.

Maximum TBARS suppression was observed.

Similarly, Figures 5 and 6 show that when goats brain homogenate was induced with iron and sodium nitroprusside it suddenly amplified the production of TBARS and triggered lipid peroxidation which resulted in the sharp rise in the production of free reactive oxygen species. Which induced stress in goat brain cells and tissues. However, when plant extract was applied to the brain homogenate it significantly inhibited the production of TBARS as a result cellular stress was reduced. The obtained results clearly show that the maximum inhibitions were observed at ( $400 \mathrm{ug} / \mathrm{ml}$ ) while the minimum inhibition was recorded at $(25 \mathrm{ug} / \mathrm{ml})$ as compared to the basal and control groups. The study disclosed the antioxidant properties of 


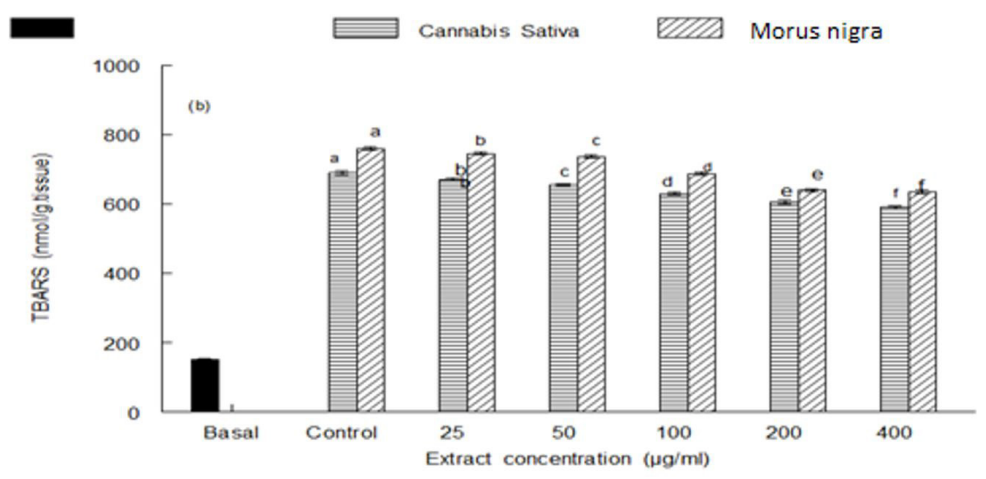

Figure 5. TBARS in goat brain induced by the iron. Values in the figure which share the different letter are considerably $(\mathrm{p}<0.05)$ different from the one another through DMRT.

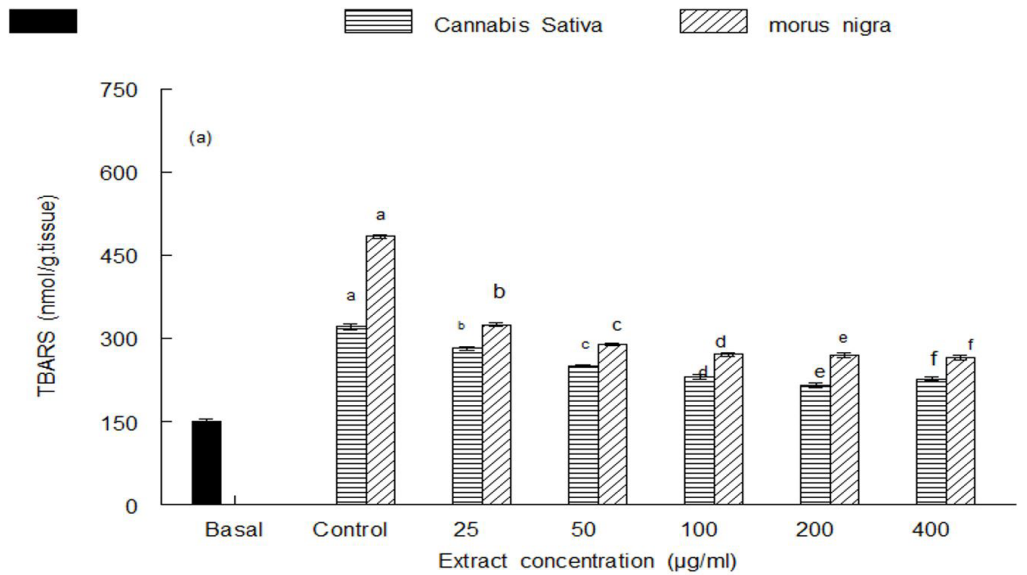

Figure 6. TBARS in goat induced by sodium nitroprusside (SNP). Values in the figure which share the different letter are considerably $(\mathrm{p}<0.05)$ different from the one another through DMRT.

target plants as several earlier studies support the current work. The antioxidative effect of $C$. sativa and M. nigra is possibly attributed to bioactive constituents which could be further investigated in upcoming studies. Oxidative stress is accountable to provoke several pathological processes like chronic inflammation, diabetes, cancer, cardiovascular diseases, etc (Reference). Since it is of the dire need to discover certain edible plant species to counter the challenges of these ailments. C. Sativa and M. nigra have cultivated plants that appeared as potential sources of antioxidants therefore can be used in food products to prevent and treat a broader group of metabolic disorders.

\section{Conclusion}

The current work was dedicated to discover certain plants with the potential to inhibit unwanted oxidative processes. Two plants were investigated for their antioxidant properties i.e., $C$. sativa and $M$. nigra. Interestingly, $C$. sativa presented a dose-dependent activity against DPPH radicals. The overall finding disclosed that $C$. sativa and $M$. nigra appeared as a potential sources of antioxidants which can be exploited for therapeutic purposes to address the plight of metabolic disorders in which oxidative stress is involved. These findings may can be useful for new drug discovery.

\section{References}

ABBAS, S.R., SABIR, S.M., AHMAD, S.D., BOLIGON, A.A. and ATHAYDE, M.L., 2014. Phenolic profile, antioxidant potential and DNA damage protecting activity of sugarcane (Saccharum officinarum). Food Chemistry, vol. 147, pp. 10-16. http://dx.doi. org/10.1016/j.foodchem.2013.09.113. PMid:24206679.

ALAM, M.N., BRISTI, N.J. and RAFIQUZZAMAN, M., 2013. Review on in vivo and in vitro methods evaluation of antioxidant activity. Saudi Pharmaceutical Journal, vol. 21, no. 2, pp. 143-152. http:// dx.doi.org/10.1016/j.jsps.2012.05.002. PMid:24936134.

ANWAR, S., KHAN, S., ALMATROUDI, A., KHAN, A.A., ALSAHLI, M.A., ALMATROODI, S.A. and RAHMANI, A.H., 2021. A review on mechanism of inhibition of advanced glycation end products formation by plant derived polyphenolic compounds. Molecular Biology Reports, vol. 48, no. 1, pp. 787-805. http://dx.doi. org/10.1007/s11033-020-06084-0. PMid:33389535.

BAJAJ, S. and KHAN, A., 2012. Antioxidants and diabetes. Indian Journal of Endocrinology and Metabolism, vol. 16, suppl. 2, pp. S267-S271. PMid:23565396. 
BATES, J.N., BAKER, M.T., GUERRA JUNIOR, R. and HARRISON, D.G., 1991. Nitric oxide generation from nitroprusside by vascular tissue: evidence that reduction of the nitroprusside anion and cyanide loss are required. Biochemical Pharmacology, vol.42, suppl., pp.S157-S165. http://dx.doi.org/10.1016/0006-2952(91)90406-U.PMid:1768273.

BOLANOS, J.P. and ALMEIDA, A., 1999. Roles of nitric oxide in brain hypoxia-ischemia. Biochimica et Biophysica Acta - Bioenergetics, vol. 1411, no. 2-3, pp. 415-436. http://dx.doi.org/10.1016/S00052728(99)00030-4.

BOSTANCI, M.Ö. and BAĞIRICI, F., 2008. Neuroprotective effect of aminoguanidine on iron-induced neurotoxicity. Brain Research Bulletin, vol. 76, no. 1-2, pp. 57-62. http://dx.doi.org/10.1016/j. brainresbull.2007.11.011. PMid:18395611.

CHEN, X., WANG, Y., SHEN, M., YU, Q., CHEN, Y., HUANG, L. and XIE, J., 2021. The water-soluble non-starch polysaccharides from natural resources against excessive oxidative stress: A potential health-promoting effect and its mechanisms. International Journal of Biological Macromolecules, vol. 171, pp. 320-330. http:// dx.doi.org/10.1016/j.ijbiomac.2021.01.022. PMid:33421468.

DEVASAGAYAM, T., TILAK, J., BOLOOR, K., SANE, K.S., GHASKADBI, S.S. and LELE, R., 2004. Free radicals and antioxidants in human health: current status and future prospects. Japi, vol. 52, pp. 794-804.

FARIA, J.V., VALIDO, I.H., PAZ, W.H., SILVA, F.M., SOUZA, A.D., ACHO, L.R., LIMA, E.S., BOLETI, A.P.A., MARINHO, J.V.N., SALVADOR, M.J., SANTOS, E.L., SOARES, P.K., LÓPEZ-MESAS, M., MAIA, J.M.F., KOOLEN, H.H.F. and BATAGLION, G.A., 2021. Comparative evaluation of chemical composition and biological activities of tropical fruits consumed in Manaus, central Amazonia, Brazil. Food Research International, vol. 139, pp. 109836. http://dx.doi. org/10.1016/j.foodres.2020.109836. PMid:33509461.

FATIMA, K., ABBAS, S., ZIA, M., SABIR, S., KHAN, R., KHAN, A. and ZAMAN, R. (2021). Indução de metabólitos secundários no estresse de nanopartículas em cultura de calos de Artemisiaannua L. Brazilian Journal of Biology, 81(2), 474-483.

FINKEL, T. and HOLBROOK, N.J., 2000. Oxidants, oxidative stress and the biology of ageing. Nature, vol. 408, no. 6809, pp. 239-247. http://dx.doi.org/10.1038/35041687. PMid:11089981.

FLOEGEL, A., KIM, D., CHUNG, S., KOO, S.I. and CHUN, O.K., 2011. Comparison of ABTS/DPPH assays to measure antioxidant capacity in popular antioxidant-rich US foods. Journal of Food Composition and Analysis, vol. 24, no. 7, pp. 1043-1048. http:// dx.doi.org/10.1016/j.jfca.2011.01.008.

HATANO, T., KAGAWA, H., YASUHARA, T. and OKUDA, T., 1988. Two new flavonoids and other constituents in licorice root: their relative astringency and radical scavenging effects. Chemical E' Pharmaceutical Bulletin, vol. 36, no. 6, pp. 2090-2097. http:// dx.doi.org/10.1248/cpb.36.2090. PMid:3240445.

KAMPA, M. and CASTANAS, E., 2008. Human health effects of air pollution. Environmental Pollution, vol. 151, no. 2, pp. 362-367. http://dx.doi.org/10.1016/j.envpol.2007.06.012. PMid:17646040.

KHALIL, A.M.A., ABDELAZIZ, A.M., KHALEIL, M.M. and HASHEM, A.H., 2021. Fungal endophytes from leaves of Avicennia marina growing in semi-arid environment as a promising source for bioactive compounds. Letters in Applied Microbiology, vol. 72, no. 3, pp. 263-274. http://dx.doi.org/10.1111/lam.13414. PMid:33063859.

LEE, K.J., OH, Y.C., CHO, W.K. and MA, J.Y., 2015. Antioxidant and anti-inflammatory activity determination of one hundred kinds of pure chemical compounds using offline and online screening HPLC assay. Evidence-Based Complementary and Alternative Medicine, vol. 2015, pp. 165457. http://dx.doi. org/10.1155/2015/165457. PMid:26504472.
LEE, H., ZHAO, X., SON, Y. and YANG, S., 2021. Therapeutic single compounds for osteoarthritis treatment. Pharmaceuticals, vol. 14, no. 2, pp. 131. http://dx.doi.org/10.3390/ph14020131. PMid:33562161.

MILLER, N.J. and RICE-EVANS, C.A., 1996. Spectrophotometric determination of antioxidant activity. Redox Report, vol. 2, no. 3, pp. 161-171. http://dx.doi.org/10.1080/13510002.1996.1174 7044. PMid:27406072.

OHKAWA, H., OHISHI, N. and YAGI, K., 1979. Assay for lipid peroxides in animal tissues by thiobarbituric acid reaction. Analytical Biochemistry, vol. 95, no. 2, pp. 351-358. http://dx.doi. org/10.1016/0003-2697(79)90738-3. PMid:36810.

ORTIZ-ANDRADE, R.R., GARCIA-JIMENEZ, S., CASTILLO-ESPANA, P., RAMIREZ-AVILA, G., VILLALOBOS-MOLINA, R. and ESTRADA-SOTO, S., 2007. $\alpha$-Glucosidase inhibitory activity of the methanolic extract from Tournefortia hartwegiana: an anti-hyperglycemic agent. Journal of Ethnopharmacology, vol. 109, no. 1, pp. 48-53. http://dx.doi.org/10.1016/j.jep.2006.07.002. PMid:16920301.

PANOSSIAN, A.G., EFFERTH, T., SHIKOV, A.N., POZHARITSKAYA, O.N., KUCHTA, K., MUKHERJEE, P.K., BANERJEE, S., HEINRICH, M., WU, W., GUO, D.A. and WAGNER, H., 2021. Evolution of the adaptogenic concept from traditional use to medical systems: pharmacology of stress-and aging-related diseases. Medicinal Research Reviews, vol. 41, no. 1, pp. 630-703. http://dx.doi. org/10.1002/med.21743. PMid:33103257.

PATIL, R., PATIL, R., AHIRWAR, B. and AHIRWAR, D., 2011. Isolation and characterization of anti-diabetic component (bioactivity: guided fractionation) from Ocimum sanctum $\mathrm{L}$.(Lamiaceae) aerial part. Asian Pacific Journal of Tropical Medicine, vol. 4, no. 4, pp. 278-282. http://dx.doi.org/10.1016/S1995-7645(11)60086-2. PMid:21771470.

RANA, D., BHATT, A., LAL, B., PARKASH, O., KUMAR, A. and UNIYAL, S.K., 2021. Use of medicinal plants for treating different ailments by the indigenous people of Churah subdivision of district Chamba, Himachal Pradesh, India. Environment, Development and Sustainability, vol. 23, no. 2, pp. 1162-1241. http://dx.doi. org/10.1007/s10668-020-00617-0.

SABIR, S., AHMAD, S., HAMID, A., KHAN, M., ATHAYDE, M., SANTOS, D., BOLIGON, A.A. and ROCHA, J.B.T., 2012. Antioxidant and hepatoprotective activity of ethanolic extract of leaves of Solidago microglossa containing polyphenolic compounds. Food Chemistry, vol. 131, no. 3, pp. 741-747. http://dx.doi.org/10.1016/j. foodchem.2011.09.026.

SABIR, S.M., ABBAS, S.R., SHAHIDA, S. and KHAN, M.F., 2020. In-Vitro antioxidant, anti-lipid peroxidative activities and In-Silico study of Terminalia chebula bioactive compounds. Clinical Phytoscience, vol. 6, no. 1, pp. 83. http://dx.doi.org/10.1186/s40816-020-00233-5.

SABIR, S., ZEB, A., MAHMOOD, M., ABBAS, S., AHMAD, Z. and IQBAL, N., 2021. Análise fitoquímica e atividades biológicas do extrato etanólico do rizoma de Curcuma longa. Brazilian Journal of Biology $=$ Revista Brasileira de Biologia, vol. 81, no. 3, pp. 737-740. http://dx.doi.org/10.1590/1519-6984.230628.

SILVA, S.B., COSTA, J.P., PINTADO, M.E., FERREIRA, D.C. and SARMENTO, B., 2010. Antioxidants in the prevention and treatment of diabetic retinopathy-a review. Journal of Diabetes Metabolism, vol. 1, no. 3, pp. 111. http://dx.doi.org/10.4172/2155-6156.1000111.

ZAGO, M.P., VERSTRAETEN, S.V. and OTEIZA, P.I., 2000. Zinc in the prevention of Fe2initiated lipid and protein oxidation. Biological Research, vol. 33, no. 2, pp. 143-150. http://dx.doi.org/10.4067/ S0716-97602000000200014. PMid:15693281.

ZAGÓRSKA-DZIOK, M., ZIEMLEWSKA, A., BUJAK, T., NIZIOŁŁUKASZEWSKA, Z. and HORDYJEWICZ-BARAN, Z., 2021. Cosmetic and dermatological properties of selected ayurvedic plant extracts. Molecules, vol. 26, no. 3, pp. 614. http://dx.doi. org/10.3390/molecules26030614. PMid:33503925. 